\title{
PRODUCTION AND PRODUCTIVITY OF AGRICULTURE IN MACEDONIA DURING THE XX CENTURY
}

\section{Blagica Sekovska ${ }^{1}$, Vasilka Popovska Trenevska ${ }^{2}$}

\begin{abstract}
"In the period of (around) 1855, Europe knows that several years ago the American Joseph Henry invented the first electromotor, but doesn't know that in some regions of Macedonia, instead of oxen, men were harnessed to plough the land" (Janevski, 1970).

Period of XX century in Macedonia was extremely turbulent, besides the fact that it was century of 4 wars $^{3}$ on this territory. This historical change has strong impact to the all-economic and social aspects of ordinary life, including agriculture. So the main aim of this paper is to enlightening little bit more situation and condition of agriculture in North Macedonia during the XX century. Methodology was mainly desk research of historical and statistical data relevant for this field and changes, which are following agricultural production and productivity in this period (XX century).
\end{abstract}

In Macedonia, during the XIX century, institutional settings established in the Ottoman Empire have been put into force. The owner of the land was the Turkish aristocrat "spahija". The people who worked on the spahija's assets were "raja".

Private agriculture in Macedonia has been established around 1912 when Macedonia was finally freed from the Ottoman occupation.

There are four phases in the historical development of agriculture and agricultural relations in Macedonia throughout history, actual within the XX century: the period of the Ottoman Empire; the period between the two World Wars; the period of Socialism (1945-1990); and the period since independence until now. ${ }^{4}$

The transition to the modern, as opposed to historic, period in Macedonia started in 1990 and continues to today.

1 Blagica Sekovska, Ph.D., Full Professor, Department of Rural Economy and Management, Faculty of Veterinary Medicine, University St. Cyril and Methodius, Lazar Pop Trajkov Street no. 5-7, 1000 Skopje, Republic of North Macedonia, Phone: +389 70708 730, E-mail: bsekovska@fvm.ukim.edu.mk

2 Vasilka Popovska Trenevska, Ph.D., Associated Professor, Department of Statistics, Faculty of Veterinary Medicine, University St. Cyril and Methodius, Lazar Pop Trajkov Street no. 5-7, 1000 Skopje, Republic of North Macedonia, E-mail: vasilka@fvm.ukim.edu.mk

3 I and II Balkan War and I and II World War.

4 For this paper is relevant only period until the 2000. 
Each of these periods has their sociological, economic and cultural characteristics. Of course, each period has different means of production and productivity that depend not only on the technological and technical development, but also, perhaps much more, on the social characteristics.

Key words: historical periods of agriculture, XX century, productivity, socioeconomic relations.

JEL $^{5}:$ Q10, Q19

\section{Introduction}

We have been trying to gather data concerning the historical development of agriculture in Macedonia for a long time. Considering the fact that the Republic of North Macedonia, even today, still places a high value on agriculture, we expected to find a lot more written material on this subject. However, the disappointment was great when we ran across indirect sources, namely that the history of agriculture in Macedonia has been carelessly elaborated in various materials that were unrelated. Considering the fact that Balkan history, and in particular Macedonian history, has been very turbulent, filled with events such as big migrations, it is logical to expect that these should be significantly reflected in the historical movements in the field of agriculture as well. Regrettably, there is not any serious research that is aimed in that direction. This elaborate only scratches the surface on the top of the iceberg in the field of agriculture in Macedonia. The themes that reach deep into the history of agriculture in Macedonia are being significantly explored in literature (both, in prose and in poetry of Macedonian authors) from where one can get considerable information and can understand the processes that have followed the development of agriculture in the country.

Agriculture is considered the oldest economic activity, which is still practiced by a significant number of people today. This activity is so closely related to the development of humanity that humans perform it without asking themselves why or how they were doing it in the past (especially those living in underdeveloped regions).

\section{Phases of the Historical Development of Agriculture in the Republic of North Macedonia during the $\mathrm{XX}$ century}

Both natural factors and socio-economic factors i.e. agricultural relations determined the development of agriculture in the Republic of Macedonia throughout history. Based on these relations, the socio-economic and historical circumstances that existed in Macedonia can be divided into several phases:

5 Article info: Review Article, Received: $2^{\text {nd }}$ July 2019, Accepted: $27^{\text {th }}$ September 2019. 
- The phase of the Ottoman Empire (from the $15^{\text {th }}$ century to the beginning of the $20^{\text {th }}$ century);

- The phase between the two World Wars (1912-1944);

- The phase of SFRY (1944- 1990);

- The phase of Independent Macedonia to present (1990-present).

Agricultural relations in the first phase are significantly denoted by the Ottoman feudal system that dominated in this region for five centuries. That is the oldest phase for which data can be found. Only sparse written data concerning agriculture in Macedonia is available. In the period of the Ottoman feudal system, the biggest part of the land was in the hands of feudal lords, "Spahija", or was collective property of the villages in forms of different pastures, meadows, woods, etc. The inhabitants of the villages, the "raja", who were cultivating the land did not have any rights to the land but were obligated to pay taxes ("arach") to the Turkish state (in older historical period, but not relevant for XX century). The raja was obligated to pay both arach (tax payed to the Sultan and to the Spahija, the so called one tenth or "desetok") and blood tax. Feudal relations in the Republic of Macedonia had some specifics and were called "cifci" relations. This derives from the term chift (a couple) and refers to the rights that one could cultivate land for themselves that can be ploughed with a pair of oxen. In Macedonia, in the period when feudal relations were predominant, but there were also "free" villagers. The "free" villagers were owners of small land not bigger than $1 / 20$ hectare. The majority of lowland villages were abided by the feudal system. The free villagers, on the other hand, were predominantly located in mountain villages.

All people within its borders were cut off the civilized world, with no access to the education and few civil rights. Time had stopped in the Ottoman Empire. Trade connections, however, started to bring in knowledge about the Western world and life there; some people had managed to get education abroad. Some became local leaders, teachers and revolutionaries. In $19^{\text {th }}$ century, weakened Ottoman Empire started losing large chunks of its territory (Vreme, 2019).

According to the reform in political system of Ottoman Empire and problems which has Ottoman Empire on the end of XIX century this agricultural relation was abandoned, and beginning of XX century brings a lot of uprising against the Ottomans, including several upraising in the territory of Macedonia.

At the beginning of the $20^{\text {th }}$ century there were 180,000 agricultural farms in Macedonia, from which 25,000 were of big and medium size, 10,000 were smaller farms, and the rest were in operated on a feudal basis. 
The fact that Macedonia had the misfortune to be inhibited from development until it was freed from Ottoman occupation (much later than its neighbours) is an important historical reality for the region. While the neighbouring countries (Serbia, Greece and Bulgaria) had declared their independence in the period from 1820 until 1860, Macedonia stayed under rule of the Ottoman Empire until 1912. The withdrawal of the Ottomans from Macedonia was followed by the bloodshedding Balkan Wars that were generally led in and around the territory of Macedonia and in which the neighbouring countries fought among each other in order to grab a bigger and better part of the Macedonian territory for themselves, thus using the advantage of a fifty yearlong independent development they had in comparison to Macedonia. II Balkan War ended with the liberation of Macedonia from the Ottoman Empire, but also with its division among Serbia, Bulgaria and Greece (with the Bucharest Agreement signed in 1913). This period was followed by migrations of the Macedonian people to overseas countries (Apostolski, 1972).

All of these events (the late liberation from the Ottoman Empire, the Balkan Wars that took place in the region of Macedonia, waves of migration, as well as the socioeconomic influence of the policies directed towards aggressive assimilation by neighbouring countries) had significant influence on Macedonia, in comparison to its neighbours, to create small, privately held agricultural farms, as legally free and economically productive.

With the start of the previous century within the area of vilayets (province) of Bitola, Thessaloniki and Skopje, there were sown 707,575 ha of land under the cereals, involving 232,571 ha under the wheat and 180,539 ha under the corn. Besides, around 113,900 ha of Macedonian agricultural land were involved in tobacco production (it represented $40 \%$ of the total agricultural production in Macedonia, while tobacco products took $78 \%$ of Macedonian exports). During the mid of $19^{\text {th }}$ century, annual production of cotton increased to $1,700,000$ okes (Turkish weight measure, where 1 oke equals to three pounds). In poppy production, until the 1900 it reached around 500 t per year. Up to 1910 there were around 70,000 ha of vineyards, with annual production of around 137 million kg of grapes. Livestock fund was significantly increased, where 250,000 persons were managing around 7.3 million of animal heads (6 million of sheep and 1.3 million of cattle), (MI-AN, 2019).

The second phase, the beginning of which preceded the I World War, had a specific impact upon the agricultural system utilized in Macedonia. The overthrow of Ottoman rule marked the end of eastern (Ottoman) feudalism, creating the possibility for new agricultural relations. Following the I World War, financial capital (at first generated from usury, and later from an emergent bourgeoisie) started to penetrate 
in the Macedonian villages. Under these conditions, maintaining the ownership structure utilized in the period before 1912 was untenable.

These movements were influenced by the colonization of the region by Turks, led, at this point in history, by a weakened Turkey in order to reinforce their governance in Macedonia. Turkey's cultural aggression originated its concerns following the successful uprisings in the neighbouring regions, and due to the consistent struggle for national freedom of the Macedonian people. After the division of Macedonia in 1913, each of the neighbouring countries, namely Serbia, Greece, and Bulgaria, tried to absorb the former Ottoman assets for their own people. The Vardar part of Macedonia was colonized by Serbs, the Aegean with Greeks and the Pirin with Bulgarians. Colonists were granted all privileges by their governments, who were attempting to strengthen the newly conquered territories. For instance, "With the Regulation for Inhabiting the South Territories" from 24.09.1920 the Macedonians were excluded from the possibility of receiving land in the vicinity of their homes, which was not the case with the colonists from Serbia. At the same time as the economic processes evolved, the occupant countries were also carrying out a cultural assimilation of the Macedonians (Apostolski, 1972).

This period was especially hard for the Macedonian people, and, as a result, mass migrations occurred which sent many Macedonians abroad in many European, but mostly overseas countries such as Canada, Australia and USA.

The historical circumstances considerably influenced the economic development and agricultural relations. At this point, the Macedonian economy was fragile, as the country had just been divided and devastated from the Balkan Wars, and was on the threshold of the I World War. As a result, Macedonia did not experience agricultural development at this point in its history.

The dissolution of feudal relations, also the constant wars and devastation, contributed towards the fact that the assets in Macedonia were predominately rural, merely seed reserves of limited size, though varied. The climate in Macedonia determined the choice of crops and allowed development of stockbreeding - merely sheep breeding and goat breeding in the mountainous regions, but one can also identify a small number of cows from the autochthonous sort, or "Busha". The production of wheat and grains was developed in the lowlands. Industrial crops, such as tobacco, cotton and poppy, which were cultivated in the same way, were also extensively produced. Cotton and tobacco were the main products of trade in this period. There was also a cultivation of mulberries that were a base for the development of raw silk production, and in the period between the two World Wars silkworm breeding was particularly developed. Viticulture was also widespread in some regions of Macedonia. However, 
in the period after the 1920's productivity in this industry began to decrease because of the emergence of phylloxera ${ }^{6}$ (Mihailov, 1960).

In general, one can say that agriculture in Macedonia in the period between the two World Wars is characterized by a great heterogeneity, underdevelopment, extensive means of production, low productivity, and agricultural variety based on the natural characteristics of the region, as well as an extraordinary technical underdevelopment. The farmers produced mainly for themselves and their family, and sold only the surplus, selling it in exchange for other products (subsistence agriculture). This means that in a period of capitalistic expansion in Europe, Macedonia still exercised the goods exchange system. Contemporaneously, during these difficult periods, Macedonia began the development of the collective system of work. The first cooperative farm was established in 1908 in the village Robovo (Mihailov, 1960).

In the Vardar part of Macedonia, separate areas also differed in terms of agricultural equipment property with commodities, agricultural inventory, then in percentage of agricultural properties that bought grain for bread, as well as the number of renters. However, in Vardar Macedonia, agricultural holdings lacked working goods. Percentage of agricultural holdings without working commodities was as follows: in Dojran District - 10.78\%; in Gevgelija District - 4.07\%; in Kavadarci District - 3.67\%; in Negotino District - 30.44\% and in the Strumica Region - 26.95\% (Cvetkovska, Gjurkovska, 2015).

Farmers' personal initiative was responsible, with political or financial aid being provided. The worldwide economic crises that began in 1929 had additionally worsened the conditions facing those involved in agriculture because of the enormous drop in prices, which caused changes in productivity (decreased production of poppy and tobacco as a result of the low prices).

After the world wars, significant focus was turned to agro-food production, becoming the one of priorities within the national economy. By carrying out the different actions and measures previously advanced development was being accelerated even more. Obtained effects were visible in all segments of production (Nikolic et al., 2017).

The real flourishing of agriculture in the Republic of Macedonia commenced after the end of the Second World War, when the third phase in the development of agriculture began. For the first time, after many centuries, the centuries-old dream of the Macedonians to have their own state became reality. However, that dream came true only for the people who lived in the Vardar region of Macedonia that participated as an equal member (Republic) in the creation of the new Yugoslavian state, which had a constitution of a federal state.

6 Phylloxera is a microscopic louse or aphid that lives on and eats roots of grapes. 
Initially, there was a process of occupying the lands through comasation and arondation (landing of land plots) as well as through creation of a system of co-op farming. Large social agro-industrial systems and practices were also established. However, some small individual agricultural units remained. This phase can be further divided into four historical periods: the period of renewal of the state devastated from the war (1944-1947); the period of collectivization (1947-1953); the period of free action of the commercial regulations (19531965); the period of loss of concept and strategy for development of agriculture (1965-1990), (Markovic, 1986).

The last phase occurred after the independence of the Republic of Macedonia and the separation from SFRY and it was the period of transition in which the economy transited from planned into the market economy. This is a significant period followed by many tumultuous reforms. Reconstruction was executed in all of the agricultural areas, from the change of the estate structure, through the change of the productivity, assortment and other agricultural features, to the euro-integration processes. The collapse of the socialist system in 1990 and the beginning of the transition period led to bleakness in agriculture in the Republic of Macedonia because it had to reconstruct its capitalist system - which it had omitted in its development. The difficulty of this process stems from not being able to refer to a renewal of a system that once existed, but to build an entirely new system of relations and to establish a proprietorial land structure (Murarcaliev, 1984).

Regarding Euro-integration, there are ongoing processes whose goal is to harmonize the Macedonian system of agricultural production with EU regulations, as well as with the Common Agricultural Policy. These processes are ongoing, so it is early to analyse the process from a historical perspective.

\section{The structure of agricultural production in the Republic of Macedonia by quality and quantity in the period of 1945-1985}

For detailed elaboration, a phase from the recent history was chosen, namely the phase after the Second World War.

The period of renewal of the country began with passing the basic regulations of the Agricultural Reform and Colonization Act, in which the first political measures in agriculture were set. Based on that Act, expropriation of the agricultural land was conducted. During this period, the socialist economy was established and compulsory purchase of agricultural products was introduced. Up to the mid of XX century, there is an attitude that agriculture is ineffective, so all investments and policies were oriented to industry as highly productive activity. Industry and farming are mutually 
dependent, where advancement of one sector necessarily initiates the development of other sector. So, agriculture represents a source of inputs for industry, while industry is focused to the production of contemporary mechanization and equipment, or production of hi-quality fertilizers and pesticides, what directly affects increase in achieved yields (Gveroski et al., 2017).

The period of collectivization was a period of a series of discouraging agricultural measures (progressive tax rates, system of bound prices, restricted land trade, complex credit policy, etc.) with the purpose of integration of the small individual agriculturalists into farming co-operatives ${ }^{7}$. The above mentioned measures, especially the investment policy, led to decreased productivity; agricultural production in this period equalled the pre-war period production. The number of cooperatives increased and stabilized by the 1950. Up to 1952 they have on disposal 364,220 ha, where 225,705 ha were arable. They provided to rural areas food and financial assets in exchange for land cultivation. They represent less than $15 \%$ of the total number of farms, while cultivate only $12 \%$ of arable land. With 1953 , the concept of cooperatives based on rural labour was left, while new form of socially owned farms was implemented (Melmet Sanjak et al., 1998).

The period of free action of the market regulations was a period in which the administrative system was removed from agriculture, which was marked by the introduction of novelties such as agricultural maximum of 10ha arable land, free land trade and the introduction new price policy, tax policy and investment policy. The biggest hustle of agriculture was carried out by the new investment policy, because of the approval of 1954 of agricultural loans with favourable interest rates $(2 \%)$ and terms of repayment (up to 30 years). Aside from the favourable loans in this period, there were other kinds of investments (issuing means without obligation of repayment), which were used for the building of several hydroameliorative systems. Because of the intensive processes of implementation of new techniques and technology, the increase of agricultural production and productivity was apparent starting during the 1957.

7 According to the system of bound prices producers of agricultural products gain money and vouchers which can be used for cheaper purchase of various industrial products. 
Graph 1. Index of agricultural production (1953-1964)

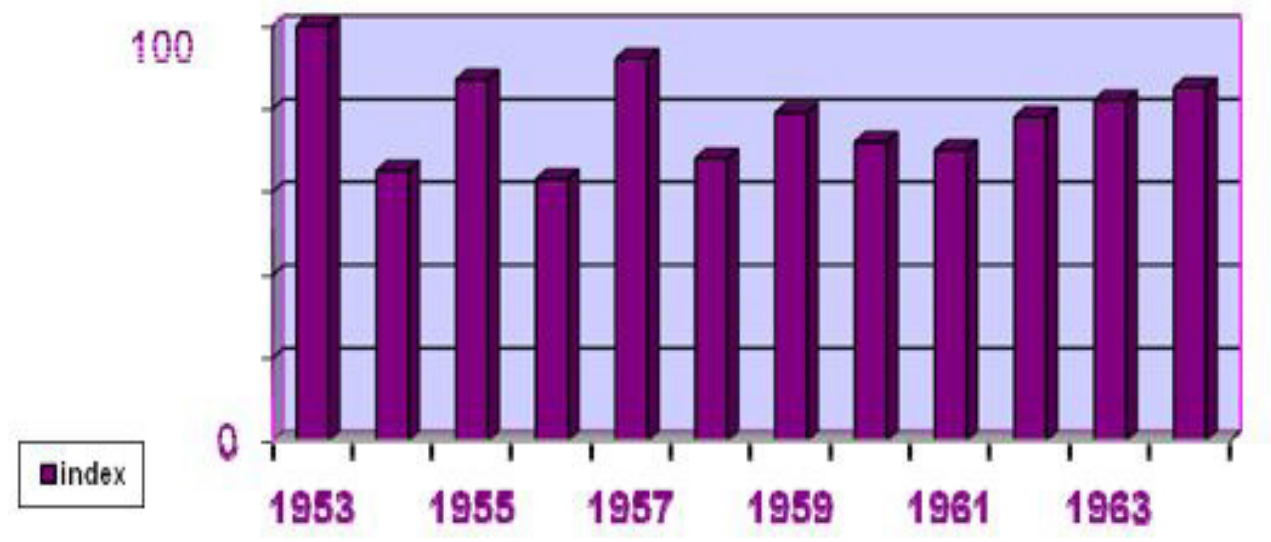

Source: Statistic annual proceedings of Socialistic Republic Macedonia, 1953-1963.

The period of loss of concept and strategy for development of agriculture led to reconciliation between the set social targets and the measures for their realization. In conditions of complex and diverse economic and agricultural structure between the republics and the provinces of SFRY, the constitution of the agricultural policy in Yugoslavia had to be based on a compromise of various interests. The dispersal of the economic crisis, the high inflation, and in particular, the decrease of the economic power of the consumers as well as the restricted material possibilities, caused the decrease of the agricultural productivity and its development.

Graph 2. Index of the agricultural production (1965-1990)

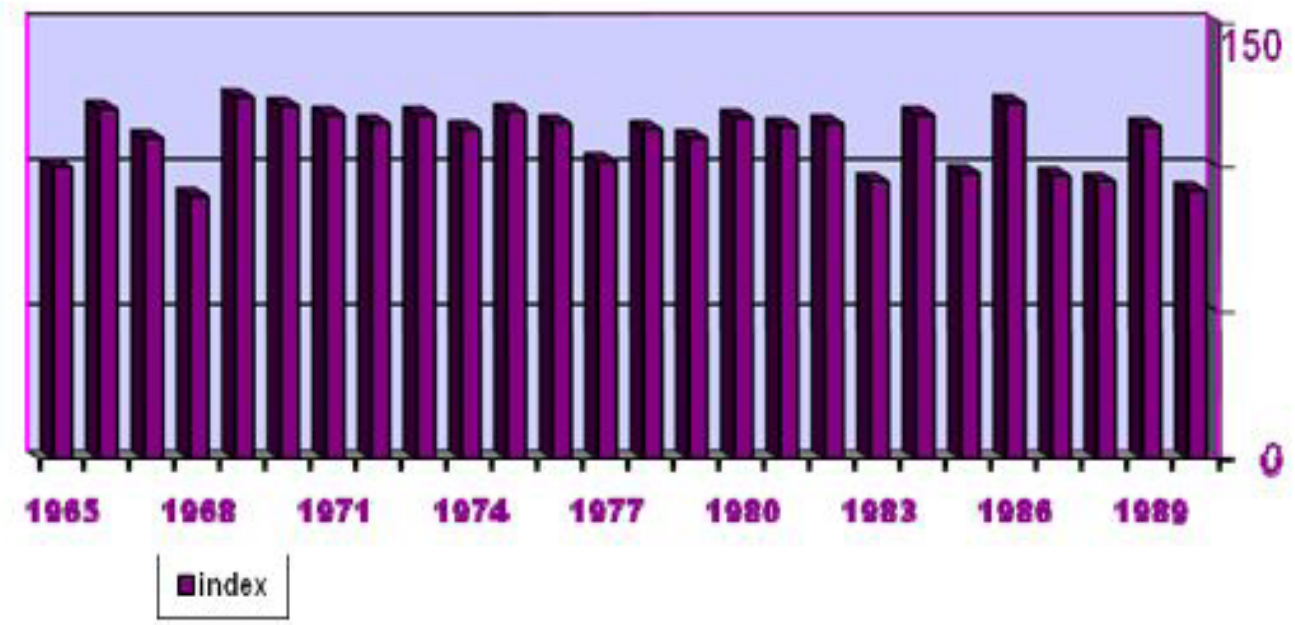

Source: Statistic annual proceedings of Socialistic Republic Macedonia, 1965-1990. 
In order to prevent the negative trend in agriculture, common measures were imposed for all the republics and provinces in the region. Measures such as fixed prices, fiscal stimuli (premiums and bonuses), and limits on exports were imposed at the federal level. Furthermore, each republic introduced local policies, such as local tax rates, ad hoc promotions of technical services, as well as fiscal stimulus packages for infrastructure development and village revitalization.

Graph 3. Average harvest kg/ha of chosen grain crops

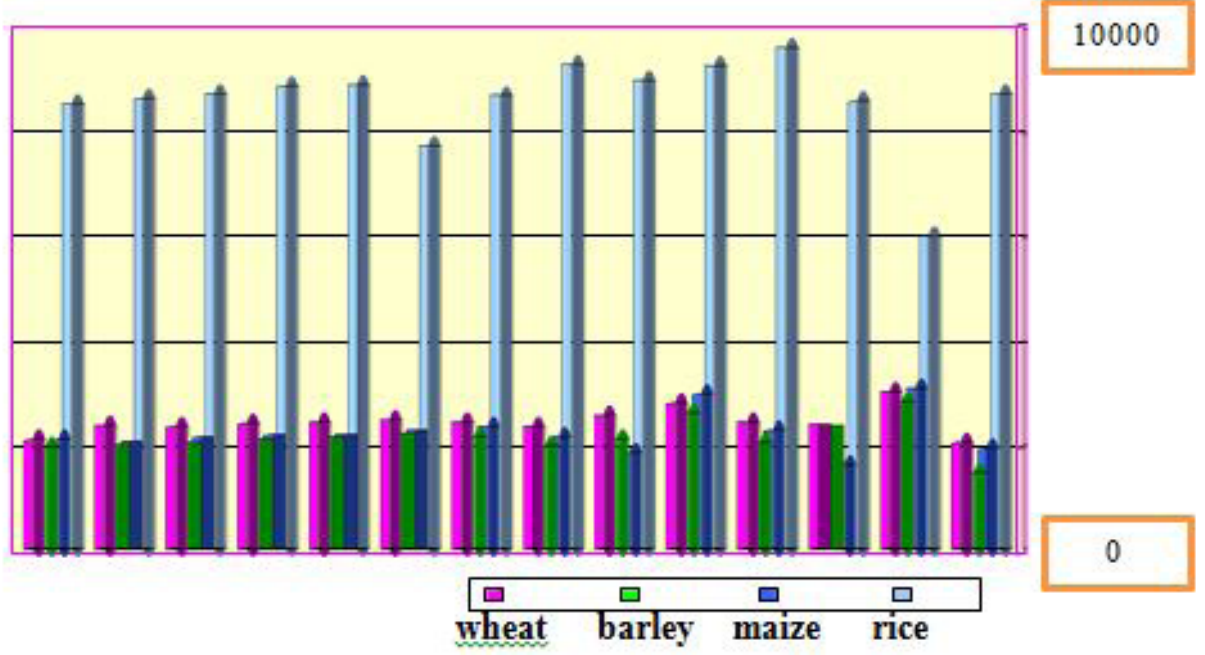

Source: Statistic annual proceedings of Socialistic Republic Macedonia, 1953-1990.

Graph 4. Average harvest kg/ha of chosen industrial cultures
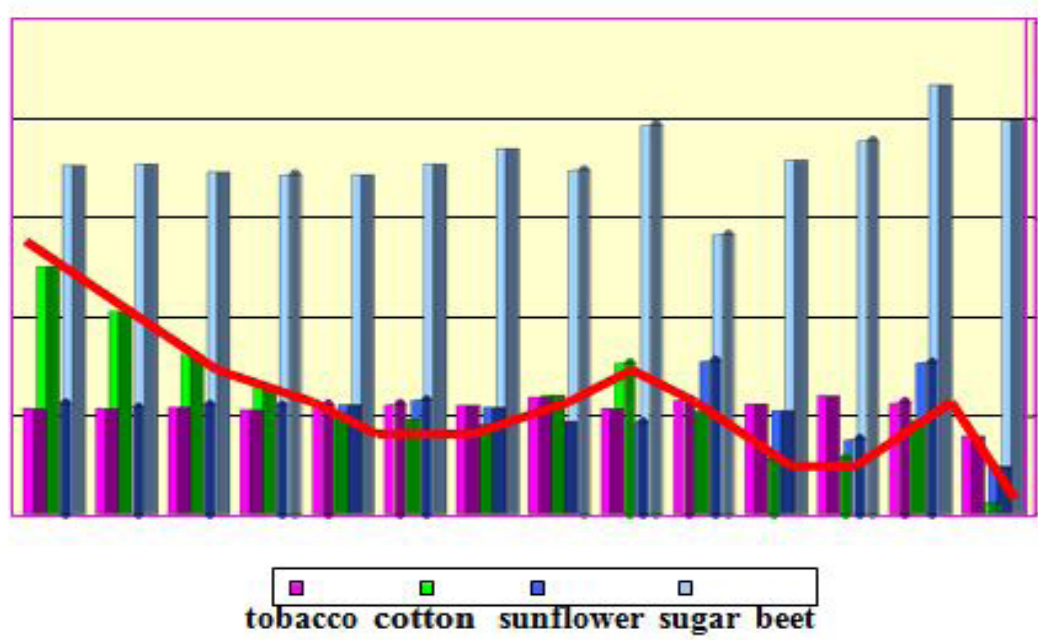

Source: Statistic annual proceedings of Socialistic Republic Macedonia, 1953-1990. 
This separation of authority in agricultural policy did not have a positive influence on the development of agriculture and the special economies. Therefore, the agricultural production that showed negative trends, the independence of Macedonia, and the occurrence of wars in the other Yugoslav republics, were followed by closure of markets in foreign countries. That hindered the promotion of agricultural production and disrupted the material value of the agriculture as a whole. How did the quota of the more significant cultures rank?

As we can notice in the two graphs above, at the end of the 1980s, the fall of productivity is apparent and it occurs due to the socio-economic circumstances in that period i.e. the end of SFRY and the beginning of the civil war. It can also be noticed that the assortment changes gradually. The most blatant example is the production of cotton that has completely ceased in the Republic of Macedonia, while it was the most dominant crop at the beginning of the century.

After the independency, so-called period of transition to the new economy (19902000) more changes in this sector are following. Before transition, agriculture has relatively high participation in GDP (8.3\% in 1990), but in 2000 participation in agriculture in general GDP increase to the $9.3 \%$. This is of decreasing of other sector participation, not of the increasing agricultural productivity in this period. If we compare periods 1981-1990 and 1991-2001 we will realized that there is serious stagnation and decreasing of total production in: industrial culture to $52.1 \%$, fruit to $70.5 \%$, grape to $81.4 \%$, vine to $75.3 \%$, etc. (Sekovska et al., 2007).

National agriculture is characterized by atomized family farms (up to $80 \%$ of farms are in range of 2.5-2.8 ha), fragmented into several parcels. State enterprises possess much larger production potential, but usually are or out of operation, or are facing the certain business limitation the most often contained in unfinished privatization. The most of pastures is in possession of the state and managed by the Public Enterprise of Pastures. Large part of the Gross Output of Agricultural (around 70\%) comes from the crop production, dominantly from vegetable production. Tomato, pepper and melon growing have the largest share within the vegetable production, making the FYRM a net exporter of fresh vegetables and vegetable products. Other significant group of agro-products are the fruits, grains, tobacco and grapes. Sector of livestock production has lower importance, with dominance of dairy farming (cow milk). Agriculture plays crucial role within the national economy, contributing the GDP creation with nearly $10 \%$, or jointly with food processing up to $16 \%$. Nearly $50 \%$ of population settle the rural areas. Generally, up to $20 \%$ of manpower is involved in agro-sector. Besides, agriculture is usually a shock absorber for socioeconomic and structural shifts within the sectors of national economy. Observation of the state of Macedonian agriculture during the period of XX century could be 
framed with the fact that in mentioned period FYRM was the first country from the region which signed the Stabilization and Association Agreement (signed in 2001, and entered into the force during the April 2004), starting from that period a new stage of its development (EC, 2011).

\section{Conclusion}

The development of agriculture in Macedonia and the region was highly dependent on the socio-economic conditions of the period. That dependence has not been relevant only for the variety of crops in certain areas, but also for the productivity and the intensity of domestication of certain crops.

This elaboration, though only a review of the topic, has attempted to systemize the understanding of the history of agriculture in Republic of Macedonia through the various historical epochs. Each of these epochs can be viewed in many different ways and from many different perspectives. The topic considered is a broad one, which would benefit from further research and analysis. Unfortunately, in the Republic of Macedonia there has been limited scholarly work dedicated to the generation of new knowledge.

Considering the fact that in the recent past the Republic of Macedonia has gone through a turbulent period, a systemic approach to understanding the impact of such periods on agricultural processes and development in the region is necessary. Dramatic socio-political and socio-economic changes have brought with them a plethora of changes in agriculture.

In order give sufficient coverage to the different aspects of the period, it has been necessary to analyse the specific agricultural policies, as well as the effects they have had on the development of agriculture in given periods. It is also necessary to take into consideration the global socio-economic and socio-political situation which was present during these periods. Such a process is the only possible manner to create an accurate picture and to describe the correlation between social and political events, which influenced agricultural policy and development. We can conclude that there was lot of up and down during the only one century, in which no so long period Macedonian agriculture develops from very subsistence agriculture to serious economic sector in the way to EU. 


\section{References}

1. Apostolski, M. (1972). History of the Macedonian People. Institute of National History, Prosvetno delo, Skopje, Macedonia.

2. Cvetkovska, N., Gjurkovska, L., (2015). Agrarian structure in Tikvesh area (according to census from 1931). Glasnik, 59:1-2.

3. EC (2011). The Former Yugoslav Republic of Macedonia - Agriculture and Enlargement. European Commission (EC), Brussels, Belgium, available at: https://ec.europa.eu/agriculture/enlargement/countries/fyrom/profile en.pdf retrieved at: 26.9.2019.

4. Gveroski, M., Stamnova, A., Risteska,A. (2017). Productivity and the productivity factors of the agricultural sector in the Republic of Macedonia. Proceedings, Horizonti 2017, Faculty of economics, Prilep, Macedonia.

5. Janevski, S. (1970). The Stubborn Ones. Makedonska kniga, Skopje, Macedonia.

6. Madison, A. (2003). The World Economy historical statistic. OECD, Paris.

7. Markovic, P. (1986). Agrarian Policy. Cultural Centre, Gornji Milanovac, Serbia.

8. Murarcaliev, A. (1984). Agrarian Policy of Macedonia. Institute of Economic Promotion, Skopje, Macedonia.

9. Melmet Sanjak, J., Bloch, P., Hanson, R. (1998). Project for the analysis of land tenure and agricultural productivity in the Republic of Macedonia. University of Wisconsin, Madison, USA.

10.MI-AN (2019). The Macedonian Economy, Past and Present. Portal of MI-AN Publishing, Skopje, Republic of Macedonia, available at: www.unet.com.mk/ mian/eco.htm, retrieved at: 26.9.2019.

11. Mihailov, I. (1960). Movement of the Agronomical Production in Two Decades (1930-39 and 1950-59) in People's Republic of Macedonia. Annual proceedings of the Faculty of Agriculture and Forestry, Skopje, Macedonia.

12.Nikolic, R., Fedajev, A., Stevanovic, V., Ilic, S. (2017). The agriculture sector in Western Balkans: Some characteristics of development. Economics of Agriculture, 64(1):275-293.

13.Sekovska, B., Kabranova, R., Anakiev, B., Arsov, Z. (2007). Influence of the Transition to the Development of Macedonian Agriculture. In: $100^{\text {th }}$ Seminar of EAAE, June 21-23 ${ }^{\text {rd }}$, Novi Sad, Serbia, European Association of Agricultural Economists, Hague, the Netherlands.

14.SSORM, Statistic annual proceedings of Republic of Macedonia for the selected years (1953-1990). State Statistical Office of the Republic of Macedonia (SSORM), Skopje, Macedonia.

15.Vreme (2019). Macedonia in the beginning of the $20^{\text {th }}$ century. Portal Vreme, Skopje, Macedonia, available at: http://vreme.com.mk/20th-century-macedonia/, retrieved at: 26.9.2019. 